\title{
THE EXERCISE GROUP TECHNIQUE ON ACADEMIC HARDINESS IN SENIOR HIGH SCHOOL STUDENTS
}

\author{
Anisa Mawarni \\ Ms, Universitas Pendidikan Indonesia, Indonesia, \\ anisa_mawarni@student.upi.edu
}

\begin{abstract}
Academic stress related Hardiness (Benishek \& Lopez, 2007). Academic hardiness provide positive framework for students to react toward academic challenges. Academic hardiness is the individual state of resilience toward academic failure: Individual who have academic hardiness display a willingness to engage in academic challenges, commit to follow all academic activities, and have control over academic performance for maximum results (Kobasa, Maddi, \& Kahn, 1982).

The purpose of this study is to determine the increasing of academic hardiness from senior high school student in Indonesia. Group exercise technique provides an exercise program to increase the commitment, control and challenge of each student. A quasi-experimental non-equivalent control group with pre-test and post-test was used with a convenience sample of students. Results of statistical analysis by paired t-tests revealed that the exercise group technique intervention have a statistically significant effect on increasing academic hardiness scores. Further academic hardiness research in senior high school, utilizing the entire academic hardiness intervention, was recommended.
\end{abstract}

Keywords: Academic Hardiness, Exercise Group Technique, Senior High School

\section{INTRODUCTION}

Stress is very potential among high school students (West, \& Russo, 2000; Misra, McKean, 2000; Dahlin, Joneborg, \& Runeson, 2005; Friedlander, Reid, Shupak, \& Cribbre, 2007). The reason is due to fear of failure in the formal education process (Tyrrel, 1992; Schafer, 1996; Gibbons, 2015; Kamtsios \& Karagiannopoulou, 2015). Students express stress in each semester with a high stress source from learning before the exam, at the exam, value competition, and from so much material to be mastered in a short time (McKean \& Misra, 2000). Academic stress comes from teaching and learning process which includes pressure for class, study duration, cheating, many tasks, get repeat value, bureaucracy, get scholarship, decision of determining department and career, and exam anxiety and time management learning (Desmita, 2010). Students experience high stress in high school when entering college and facing entrance test to be 
the most acute source of tension and stress (McGowen, Gardner, \& Fletcher, 2006; Gibbons, Dempster, \& Moutray, 2008; Heikkilä, Lonka, Niemine, \& Niemivitra, 2012; Gibbons, 2015). Most studies show academic stress associated with hardiness (Benishek \& Lopez, 2001). Weak personality is the trigger of stress that even occur in the academic domain, do not have the commitment, self-control and consider the difficulty with pessimistic attitude is the attitudes possessed by individuals with weak personality (Karimi \& Venkatesan, 2009).

Academic hardiness provides a framework for students to react to academic challenges (Benishek et al., 2005). A positive relationship between the three cognitive processes used in academic hardiness, challenge, commitment, and control (Lifton, Seay, \& Bushko, 2000). Previous studies support the assertion that the high academic stress that students experience is due to the low academic hardiness of the students (Misra, McKean, West, \& Russo, 2000; Dahlin, Joneborg, \& Runeson, 2005; Friedlander, Reid, Shupak, \& Cribbre, 2007). Academic hardiness is still very little studied in the provision of preventive measures in high school (Creed, Elizabeth G. Conlon, \& Dhaliwal, 2015). Therefore, it takes certain effort in developing academic hardiness so that individuals have high learning motivation (Maddi, Harvey, Khoshaba, Fazel, \& Resurreccion, 2009), self-efficacy and positive attitude goes to Higher Education (Benishek \& Lopez (2001).

The nature of hardiness helps protect individuals from the effects of stress and predicts future well-being (Cole, Field, \& Harris, 2004). The positive impact that resilience has on the academic environment is to be expected. Academic hardiness as a one dimensional construct, as well as a multi-dimensional nature with steps: commitment, control and challenge (Benishek et al., 2005; Benishek \& Lopez, 2001; Creed et al., 2013; Kamtsios \& Karagiannopoulou, 2014).

Exercise techniques contribute to the body's knowledge of the nature of academic hardiness, which can help in developing a better understanding of the variables that affect academic achievement and academic outcomes, such as the success and fulfillment of future work (Coetzee \& Harry, 2014). Excersises technique is a method of service in group guidance in the process of Guidance and Counseling. Guidance and Counseling is a pedagogical effort to help every individual including teenagers to develop themselves optimally (Prayitno \& Amti, 2010). Guidance and Counseling Service has an important role for every student in the school, family, and society in general (Kartadinata, 2011). Implementation of academic hardiness is an individual able to have optimistic attitude, physical and mental health, and personality development (Maddi, 2006), effective leadership (Bartone, 2009), well-being, (Enccles, \& Barbel, 2004), and achievement of pride (Maddi, Harvey, Khoshaba, Mostafa Fazel, 2012). This study aims to determine the value of academic hardiness of students as well as the influence of group guidance intervention with excersises techniques toward high school student academics. Researchers only take one school as the object of research.

\section{THEORETICAL FRAMEWORK}

\subsection{Academic Hardiness}

Academic hardiness evolved from the concept of hardiness that born from existential psychology (Ferreira, 2012). This hardiness is viewed in terms of humans in search of authenticity by creating personal meaning through self-reflection, decision-making, and actions that encourage growth (Kobasa,1979; Maddi \& Kobasa, 1984). Academic hardiness is reflected in the learning, growth-oriented personality style (Sheard \& Golby, 2007). High levels of hardiness show authentic life; not looking for ways to avoid stressful events, but the individual draws strength from the difficulties facing and overcoming obstacles as a challenge. (Carr, Kelley, Keaton, \& Albrecht, 2011).

Hardiness is introduced as a research in the field of education, in an effort to ensure the positive impact that hardiness can be had in academic settings (Benishek \& Lopez, 2001; Kamtsios \& Karagiannopoulou, 2011). The formulation of the academic hardiness meaning is defined by Benishek and Lopez (2001) (Benishek \& Lopez, 2001; Benishek, Feldman, Shipon, Mecham, \& Lopez, 2005), provides a framework for understanding how students react to academic challenges (Benishek, et al., 2005 ). Academic hardiness develops a relationship between hardiness behavior and type of behavior that concerns in learning and performance components as an ideal student.

The academic hardiness component is defined as follows: a commitment to the willingness of students to spend a consistent effort and make personal sacrifices to achieve academic excellence, regardless of the content or demands of the academic process. Challenges are defined as focused efforts to always try, great efforts of students to achieve goals, in the academic process and experience to justify the actions embedded in the student's personal. Control is defined as students' belief that students have the capacity to achieve desired educational outcomes from personal effort and through effective emotional self-regulation in the face of academic pressure and disappointment (Benishek, et al., 2005). 


\subsection{Group Exercise}

Group exercises pioneered by Jacob. Group exercises emphasize the process of group dynamics that requires active group members in activities. Group activities can help students learn many skills, such as communication skills, trust, cooperation, and ability to support each other (Rusmana, 2009, pp. 15-17). There are reasons to use group exercises: developing discussions, participation, focusing groups, raising a focus, providing opportunities for experiential learning, giving useful information counselors, giving pleasure and relaxation (Jacob, 2012, pp. 223-245).

The stages of the implementation of group guidance are divided into four stages. (Glading, 2012; Rusmana, 2009) Four stages of group guidance: the beginning of a stage, the transition stage in a group, the working stage in a group, and the termination of a group. The following group guidance in the form of developing students' academic toughness with group exercise techniques: a). The beginning of a stage; namely: Statement of purpose, group formation, b). The transition stage in a group: Do stroming and norming. Group leaders conduct group reconciliation and restructuring by division of tasks and contracts. c) The working stage in a group, namely: Experimentation. Identification of the group leader that performs a one-step reflection by identifying the list and understanding of group members in commitments made to reduce the overall list that has been written in the writing exercise (commitment); Analysis, group leaders do reflection. Improvement plans are realized in the process of completing the lists that makes students feel stressed in subsequent guidance; Generalization, the group leader performs the final stage of reflection by inviting the group members to create a control system so that the resolution in stage two can be continuously done to achieve the expected objective (Control). d) Termination of a group: namely: General reflection, group leader invites group members to review or recall the process of guidance that has been done; then the counselor provides the process of movement exercise with home spot techniques, namely the participants are asked to make a circle and holding hands.

\section{METHOD}

The study design uses quasi experimental non-equivalent with pre-test and post-test. The purpose of the experimental quasi-experimental design is to examine the cause and effect of the relationship between independent and dependent variables (Burns and Grove, 2009). Samples that being used are high school students in Bandung, West Java Province Indonesia. The total sample is 68 students. The samples were dominated by women consisting of 42 students and 26 male students. Age ranges from 14-18 years ( $M=$ 15). The sample size for the experiment in this study amounted to 28 students (control group, $n=17$, experimental group, $\mathrm{n}=17$ ). The data collection method used is the development of Academic Hardiness Scale (Benishek \& Lopez, 2001). Academic Hardiness Scale (AHS) has been widely used in several studies for high school students (Golightly, 2007; Karimi \& Venkatesan, 2009). The scale can help the development of academic hardiness scale that can be made to know the profile of academic hardiness in the context to be studied. The conceptualisation of academic hardiness can be more widely researched in different stages of life, different groups, and in different cultural settings as controls of research control (Benishek et al., 2005; Chan, 2000; Green, Grant, \& Rynsaard, 2007). However, in the main focus of this study is on the approach in the development of academic hardiness for High School students.

\section{RESULTS}

From research done in one of high school in Bandung, yielded data which strong enough where student academic hardiness is still very low $(M=26,3)$ seen from average score and percentage per aspect. The value of academic hardiness is said to be high above the number 36 for the total number of aspects (Benishek, 2011) Based on research about the acquisition of academic profile of hardiness on high school students are as follows:

Tabel. 4.1

Component of Academic Hardiness

\begin{tabular}{|c|c|c|c|}
\hline No & Academic Hardiness & Yes & No \\
\hline $\mathbf{1}$ & Commitment & $66,5 \%$ & $33,5 \%$ \\
\hline $\mathbf{2}$ & Control & $22,7 \%$ & $77,3 \%$ \\
\hline $\mathbf{3}$ & Challenge & $25,6 \%$ & $74,4 \%$ \\
\hline
\end{tabular}

In the experimental analysis of independent t-test was calculated on the academic hardiness of pre-test and was considered to emphasize the raw value to determine the group equations so that the study groups were 
comparable. Samples taken from those with a score range for total academic hardiness are 17 to 39 , with a midpoint of 26. Higher scores reflect greater academic hardiness that is above 36 (Maddi and Khoshaba, 2001). The total default value $(N=68)$ for pre-test academic hardiness has a minimum of 18 and a maximum of 39 with an average of 26.5. The average value of academic hardiness pre-test is $(M=23)$. For the experimental group $(n=17)$, for the control group $(n=17)$. Scores ranged from a minimum of 17 to 28 in the experimental group and 18 to 30 in the control group.

The paired t-test was computed to compare the mean of the post-test score score to the mean academic hardiness score of the experimental group $(n=17)$, who participated in the exercise technique to test the student's academic hardiness improvement. The paired t-test shows a significant difference. The value of academic hardiness in women based on the results of pre-test and post-test is considered higher than in men $($ female $=29$, male $=22$ ).

Tabel 4.2

Test of Normality

\begin{tabular}{|l|c|c|c|}
\hline & \multicolumn{3}{|c|}{ Kolmogorov-Smirnov $^{\mathrm{a}}$} \\
\hline & Statistic & Df & Sig. \\
\hline PRE & .155 & 17 & .200 \\
\hline POST & .131 & 17 & .200 \\
\hline
\end{tabular}

Data using the kolmogorov-smirnov test resulted in normal distorted pretest data because the sign $>$ alpha value $0.05 ; 0.2>0.05$, and post-test data distributed normal due to sign > alfa 0,$05 ; 0.2>0.05$. Then using the non parametric statistical test that is Wilcoxon test.

Tabel 4.3

Paired Samples Test of academic hardiness

\begin{tabular}{|c|c|c|c|}
\hline & & & Pair 1 \\
\hline & & & PRE - POST \\
\hline Paired & Mean & & -6.294 \\
\hline Differences & Std. Deviation & & 3.331 \\
\hline & Std. Error Mean & & .808 \\
\hline & $95 \%$ Confidence Interval & Lower & -8.007 \\
\hline & of the Difference & Upper & -4.581 \\
\hline $\mathrm{T}$ & & & -7.791 \\
\hline Df & & & 16 \\
\hline Sig. (2-tailed & & & .000 \\
\hline
\end{tabular}

Sign value less than alpha 0.05 then $\mathrm{Ho}: 0,00<0,05$, hence there is significant difference of pretest and posttest score of student. Here are the results of pre-test and post-test per aspect of academic hardiness using wilcoxon test.

Tabel 4.4

Statistics of test commitment

\begin{tabular}{|l|c|}
\hline & post.komitmen - pre.komitmen \\
\hline$Z$ & $-1.466^{\mathrm{a}}$ \\
\hline $\begin{array}{l}\text { Asymp. Sig. (2- } \\
\text { tailed) }\end{array}$ & .143 \\
\hline
\end{tabular}

On the comitment aspect $(Z=-1.466,2$-tailed $=0.143)$, sign: $0.143>0.05$. So there is no significant difference between pretest and posttest score of students on commitment aspect. 
Tabel 4.5

Paired Samples Test of Control

\begin{tabular}{|c|c|c|c|}
\hline & & & Pair 1 \\
\hline & & & pre.kontrol - post.kontrol \\
\hline Paired & Mean & & -2.176 \\
\hline Differences & Std. Deviation & & 1.976 \\
\hline & Std. Error Mean & & .479 \\
\hline & $95 \%$ Confidence Interval & Lower & -3.192 \\
\hline & & Upper & -1.161 \\
\hline $\mathrm{T}$ & & & -4.542 \\
\hline Df & & & 16 \\
\hline Sig. (2-tailec & & & .000 \\
\hline
\end{tabular}

In control aspect (2-tailed sign: 0.00$) 0,00<0,05$, hence there is significant difference of pre-test and posttest score of student on control aspect.

Tabel 4.6

Paired Samples Test of Challange

\begin{tabular}{|l|l|c|}
\hline \multicolumn{2}{|l|}{} & \multicolumn{1}{|c|}{ Pair 1 } \\
\cline { 3 - 3 } \multicolumn{2}{|l|}{} & $\begin{array}{c}\text { pre.tantanfgan - } \\
\text { post.tantangan }\end{array}$ \\
\hline \multirow{2}{*}{$\begin{array}{l}\text { Paired } \\
\text { Differences }\end{array}$} & Mean & -3.647 \\
\cline { 2 - 3 } & Std. Deviation & 1.935 \\
\cline { 2 - 3 } & Std. Error Mean & .469 \\
\cline { 2 - 3 } & $\begin{array}{l}\text { 95\% Confidence Interval } \\
\text { of the Difference }\end{array}$ & -4.642 \\
\cline { 2 - 3 } & Lower & -2.652 \\
\hline T & -7.773 \\
\hline Df & Upper & 16 \\
\hline Sig. (2-tailed) & .000 \\
\hline
\end{tabular}

Likewise on the challenge aspect (2-tailed sign: 0.00 ), $0.00<0.05$, So there is a significant difference in pretest and posttest score of students on the challenge aspect. In the pre test group and post-test, the female students achieved an average score of 29 and the male was 22.

\section{DISCUSSION}

The value of academic hardiness pre-test is on average score 23 and post-test 29.2 where the value is still far to reach the value of 36 because the value of hardiness of good student is at value 36 (Benishek, 2011), then result of pre test show that the students' academic hardiness score is below the average, in terms of commitment, control and challenge although the students are at $66 \%$ in the comitment aspect, but very low on the aspects of control and challenge, each at only $22.7 \%$ and $25.6 \%$. The value of academic hardiness indicates a significant increase due to the intervention given, statistically the value of academic hardiness increases and shows positive growth in students although still far from the ideal value of academic hardines. Attitude hardiness is a cognitive and emotional system that is a buffer of educated personality and oriented to positive development (Maddi, 2006).

The value of academic hardiness in women based on pre test result and post-test is higher than men, in accordance with Rice's direction (1997) showed through the teaching of women skill is easier to overcome stress when compared with men, women find more way to reduce stress compared to men. So also with the 
results of research Hensel and Research Stoelting-Gettelfinger (2011); Goff (2011) through Stress Signal Signs (SWS) and 51-item Student-Life Stress Inventory (SSI) to measure personal and academic stressors. Women have more hardiness in self-control and resilience in every challenge and test because the main reason is that women are more detailed than men in every single thing they do.

Analysis with paired t-test showed that group guidance intervention with excercises technique to improve academic hardiness significantly influenced statistically to high school students. Explanations for academic hardines pre-test and post-test significance are statistically due to the effects of group counseling stages on the experimental group used in accordance with the stages of group guidance and in-depth training development. The stages of the implementation of group guidance is divided into four stages (Glading, 2012; Rusmana, 2009). The four stages of group guidance are: the beginning a stage, the transition stage in a group, the working stage in a group, and the termination of a group. Where in the experimental treatment at work stages done more than once to deepen the skills of students primarily to develop student self-control toward academic.

Students can only achieve a minimum change score after an Intervention made on the commitment aspect. Similarly, the average value of the overall academic hardiness change in the post-test only rises slightly from the pre test although it is said to be significant in a statistical test. The results are in accordance with the logic of the findings following the hardiness Rice (1997) student academic literature in a 6-week hardiness academy intervention in a sample of exclusive women who have an above-average academic score, so that treatment is treated to produce statistical significance with an average rate of high change in post-test. While in the present study, the initial sample had a low average academic value as it continued to rise at a not-sohigh grade, while in the student's commitment to pre-test and post-test, the student scores were almost identical due to a non-escalating understanding of the commitment aspect, related to the initial value and also the students' knowledge. Maddi et al., (1998) found that the treatment of hardiness intervention experienced an increase of more than two conditions through relaxation/meditation and passive listening, and the insignificant factor in the commitment aspect due to the lack of modification in the techniques used despite of the results from the study of Maddi et al., (2002) evaluated the effectiveness of hardiness interventions in students where the hardiness post-test score was higher than that of academic hardines in pre-test. Another plausible explanation for insignificant results on commitment and a low average value of improvement is in methodological weaknesses; data collection is only done in one school because researchers are limited to a minimum acceptable period of five weeks for the basic components of skills in the training process. It is not appropriate for high school students to learn the concepts of commitment, control and academic challenges in a short time to be able to explore statistically generated values and figures.

Another obstacle in this study is the lack of representation of the male sample in this study. In addition, additional studies and modifications of existing theories on the subgroup of academic hardiness (Khoshaba \& Maddi, 2008; Benishek, 2011), and excercise group techniques assess congruence in the design of the study and identify correspondence between the research, the experimental results show consistency with academic hardiness, but gaps and inconsistencies with academic hardiness on the commitment aspect. The process of group excersise is not deep at every stage.

\section{CONCLUSIONS}

Stress academic still exists in High School education. Empowering counseling and guidance services for students are able to improve skills to be able to have academic commitment, control and challenges. Further theoretical proportions and methodology of research and evaluation are needed to improve the academic hardiness of high school students.

High school students have low academic hardiness score with academic hardiness aspect: 66\% commitment, $22.7 \%$ control, and $25.6 \%$ challenge. There is a difference of academic hardiness value of high school students who follow group guidance activity with excercise technique and who do not get group guidance service with excercise technique. 
The implications for Guidance and Counseling from this research are the foundation for the development of Guidance and Counseling service practice theory in the field of learning. This research needs to continue to be done in finding the best way to increase academic commitment, control, and challenge as a whole and there by develop on a comprehensive academic hardiness assessment on each component of academic hardiness. Models to modify adaptation theory to the perceived pressure in high school about academic hardiness will serve as a framework to guide further research studies. Developing academic hardiness on adaptive and transformational academic stress management is a must to raise reliable human resources to face future challenges.

\section{ACKNOWLEDGEMENT}

The author would like to acknowledge and express my greatest gratitude to the Indonesia Endowment Fund for Education (LPDP) for its support of Anisa Mawarni's research. And the author would also like to thank Mrs. Dr. Nani Sugandi, M. Pd., and Dr. Ilfiandra., M. Pd. for their assistance, advice, and support during this research.

\section{REFERENCE LIST}

Bartone, P. T. (2006) Resilience Under Military Operational Stress: Can Leaders Influence Hardiness. Military Psychology, 18(Suppl.), S131-S148 Copyright @ 2006, Lawrence Erlbaum Associates, Inc.

Bartone, P., Roland, R., Picano, J., \& Williams, T. (2008). Psychological hardiness predicts success in US Army Special Forces candidates. International Journal of Selection and Assessment, 16, 78-81. doi:10.1111/j.1468-2389.2008.00412.x

Benishek, L., \& Lopez, F. (2001). Development and initial validation of academic hardiness scale. JournalofCareerAssessment,9,333-352. http: // journals. sagepub. com/doi/pdf/10. 1177/106907270100900402

Benishek, L., Feldman, J., Shipon, W., Mecham, S., \& Lopez, F. (2005). Development and evaluation of the revised academic hardiness scale. Journal of Career Assessment, 13, 59-76. DOI: $10.1177 / 1069072704270274$

Burns, N., Grove, S.K., 2009. The Practice of Nursing Research: Appraisal, Synthesis and Generation of Evidence, 6th ed. Saunders Elsevier, St. Louis, MO.

Chan, D. (2000). Dimensionality of hardiness and its role in the stress-distress relationships among Chinese adolescents in Hong Kong. Journal of Youth and Adolescence, 29, 147-161. doi: 10.1023/A:1005100531194

Coetzee, M., Harry, N. (2014). Gender and hardiness as predictors of career adaptability: an exploratory study among Black call centre agents South African. Journal of Psychology 2015, Vol. 45(1) 81-92 Reprints and permissions: sagepub.co.uk/journalsPermissions. nav doi: 10. 1177/0081246314546346sap.sagepub.com

Cole, M., Field, H., \& Harris, S. (2004). Student learning motivation and psychological hardiness: Interactive effects on students' reaction to a management class. The Academy of Management Learning and Education, 3(1), 64-85. doi: 10.5465/AMLE.2004.12436819

Creed, P., Conlon, E., \& Dhaliwal, K. (2013). Revisiting the academic hardiness scale: Revision and revalidation. Journal of Career Assessment, 21(4), 537-554, doi: 10.1177/1069072712475285

Crowley, B., Hayslip, B., \& Hobby, J. (2003). Psychological hardiness and adjustment to life events in adulthood. Journal of Adult Development, 10(4), 237-248, doi: 10.1023/A:1026007510134

Dwyer, A. L., \& Cummings, L. (2001). Stress, self-efficacy, social support and coping strategies in university students. Canadian Journal of Counseling, 35(3), 208-220.

Eccles, J., Vida, M., \& Barber, B. (2004). The relation of early adolescents' college plans and both academic ability and task-value beliefs to subsequent college enrollment. The Journal of Early Adolescence, 24, 63-77. doi:10.1177/0272431603260919 
IJAEDU- International E-Journal of Advances in Education, Vol. III, Issue 9, December 2017

Feld, L.D., Shusterman, A. (2015). Into the pressure cooker: Student stress in college preparatory high schools. Journal of Adolescence. 41 (2015) 31 e42 http: //dx. doi. org/10. 1016/j. adolescence. 2015.02.003

Ferreira, A. A. (2012). Nutritional Status and Growth of Indigenous. Associates, Inc.

Friedlander, L., Reid, G., Shupak, N., \& Cribbre, R. (2007). Social support, self-esteem and stress as predictors of adjustment to university among first year undergraduates. Journal of College Student Development, 48(3), 259-274. p. 259-274 | doi: 10.1353/csd.2007.0024

Gibbons, C. (2015). Stress, eustress and the national student survey. Psychology of Teaching Review, 21(2), 86-91.

Gibbons, C., Dempster, M., \& Moutray, M. (2008). Stress and eustress in nursing students. Journal of Advanced Nursing, 61(3), 282-290, doi: 10.1111/j.1365-2648.2007.04497.x

Glading, T. Samuel. (2012). Konseling: Profesi yang Menyeluruh, Indeks: Jakarta.

Heikkila, A., Lonka, K., Niemine, J., \& Niemivitra, M. (2012). Relationships between teacher students' approaches to learning, cognitive and attributional strategies, well being and study success. Higher Education, 64, 455-471,doi: 10.1007/s10734-012-9504-9

Indreicaa, E. S., Cazan, A. M.,Truta. C. (2011). Effects of learning styles and time management on academic achievement. Social and Behavioral Sciences. 1096-1102 doi:10.1016/j.sbspro.2011.10.214

Jacobs, et al. (2012). Group Counseling: Strategies and Skills. USA: Brook/Cole

Jameson, P. R. (2013). The effects of a hardiness educational intervention on hardiness and perceived stress of junior baccalaureate nursing students. Nurse Education Today http://dx.doi.org/10.1016/j.nedt.2013.06.019 Reisberg, 2000),

Kamtsios, S., \& Karagiannopoulou, E. (2015). Exploring relationships between academic hardiness, academic stressors and achievement in university undergraduates. Journal of Applied Educational and Policy Research, 1(1), 53-73.

Karagiannopoulou \& Kamtsios. (2016) Multidimensionality vs. unitary of academic hardiness: An under explored issue. Review under responsibility of Academic World Education and Research Center. Elsevier Inc. http://dx.doi.org/10.1016/j.lindif.2016.08.008

Karimi, A., \& Venkatesan, S. (2009). Mathematics anxiety,mathematics performance and academic hardiness in high school students. International Journal of Educational Sciences, 1(1), 33-37.

Kartadinata, Sunaryo. (2011). Menguak Tabir Bimbingan dan Konseling Sebagai Upaya Pedagogis. Bandung: UPI Press

Knowlden, A,. Sharma, M,. Kanekar, A., Ashutoshatri (2013). Sense Of Coherence and Hardiness as Predictors of The Mental Health of College Students. Int'l. Quarterly of Community Health Education, Vol. 33(1) 55-68, Baywood Publishing Co., Inc. doi: http://dx.doi.org/10.2190/IQ.33.1.e http://baywood.com

Kobasa S.C. (1979). Stressful life events, personality, and health- Inquiry into hardiness. Journal of Personality and Social Psychology. 37 (01): 1-11.

Kobasa, S. C. (1979a). Personality and resistance to illness. American Journal of Community Psychology, 7 , 413-423. doi: 10.1007/BF00894383;

Kobasa, S. C. (1979b). Stressful life events, personality, and health: An inquiry into hardiness. Journal of Personality and Social Psychology, 37, 1-11. doi:10.1037/0022-3514.37.1.1

Lifton, D., Seay, S.,McCarly, N., Olive-Taylor, R., Seeger, R., \& Bigbee, D. (2006). Correlating hardiness with graduation persistence. Academic Exchange Quarterly, 10, 277-283. Retrieved from http://rapidintellect. com/AEQweb

Maddi, S. (2005). On hardiness and other pathways to resilience. American Psychologist, 60(3), 261-272.

Maddi, S., Khoshaba, D., Jensen, K., Carter, E., Lu, J., \& Harvey, R. (2002). Hardiness training for high-risk undergraduates. NACADA Journal, 22, 45-55. doi: http://dx.doi.org/10.12930/0271-9517-22.1.45

Maddi, S., R., \& Khosaba. D., M. (2005). Risilience at Work. New York: American Managemen Association. 
Maddi, S.R., Harvey, R.H., Khoshaba, D.M., Fazel, M., Resurreccion, N., 2009. Hardiness training facilitates performance in college. The Journal of Positive Psychology 4, 566-577.

http://dx.doi.org/10.1080/17439760903157133.Maddi, Harvey, Khoshaba, Mostafa Fazel, 2012).

Maddi, S.R., Harvey, R.H., Khoshaba, D.M., Lu, J.H., Persico, M., Brow, M., 2006. The personality construct of hardiness, III: relationships with repression, innovativeness, authoritarianism, and performance. Journal of Personality 74, 575-598. http:// dx.doi.org/10.1111/j.1467-6494.2006.00385.x.

Misra, R., McKean, M., West, S., \& Russo, T. (2000). Academic stress of college students: Comparison of student and faculty perceptions. College Student Journal, 34(2), 236-245. navajo american indian high school student. Dissertation.

Nazmiye, C. Civitcia, A. (2015). Social Comparison Orientation, Hardiness and Life Satisfaction in Undergraduate Students. Peer-review under responsibility of Academic World Research and Education Center. doi: 10.1016/j.sbspro.2015.09.062

Prayitno, \& Amti, (2010). Dasar-Dasar Bimbingan dan Konseling. Jakarta: PT. Rineka Cipta.

Rice, M. (1997) The effects of a structured hardiness training intervention program for stress on university women. Unpublished manuscript

Robotham, D. (2008). Stress among higher education students: Towards a research agenda. Higher Education, 56, 735-746.

Rusmana, N. (2009). Bimbingan dan Konseling kelompok di sekolah: metode teknik, dan aplikasi. Bandung:Rizqi Press.

Sancheza, M. G. (2014). The Hardiness in People at Work as a Source of Corporate Communication for Image Building. Social and Behavioral Sciences 155, 48 - 52. doi: 10.1016/j.sbspro.2014.10.254

Sheard, M. (2009). Hardiness commitment, gender, and age differentiate university academic performance. British Journal of Educational Psychology, 79, 189-204. doi:10.1348/000709908X304406

Sheard, M., \& Golby, J. (2006). Effect of a psychological skills training program on swimming performance and positive psychological development. International Journal of Sport Psychology, 4, 149-169. doi: 10.1080/1612197X.2006.9671790

Sheard, M., \& Golby, J. (2007). Hardiness and undergraduate academic study: The moderating role of commitment. Personality and Individual Differences, 43, 579-588. Retrieved from http://dx.doi.org/10.1016/j.paid. 2007.01.006Yeo\& Lie, 2017)

Stoelting-Gettelfinger, Goff (2011); Effect of a psychological skills training program on swimming performance and positive psychological development. International Journal of Sport Psychology, 4, 149-169. doi: 10.1080/1612197X.2006.9671790

Tyrrel, J. (1992). Sources of stress among psychology undergraduates. Irish Journal of Psychology, 13, 184-192.

Yeo, S. K., Lee, W. K. (2017). The Relationship between Adolescents' Academic Stress, Impulsivity, Anxiety, and Skin Picking Behavior. Asian Journal of Psychiatry http://dx.doi.org/10.1016/j.ajp.2017.03.039

Yusuf. S. LN. (2011). Psikologi Perkembangan Anak dan Remaja. Bandung. PT Remaja Rosdakarya Offset. 